\title{
A Further Extension of the In Vivo Oxygen-Dissociation Curve for the Blood of the Newborn Infant*
}

\author{
Nicholas M. Nelson, L. Samuel Prod'hom, $\dagger$ Ruth B. Cherry, and \\ Clement A. Smith \\ (From the Department of Pediatrics, Harvard Medical School, and the Boston Lying-in \\ Hospital, Boston, Mass.)
}

The oxygen-dissociation curve of human fetal blood has been the subject of several previous investigations (1-6). At saturations below $80 \%$ the curve has been described with considerable accuracy and, as in other mammalian young, is known to be displaced to the left of that for adult blood although both curves share a similar shape. Most studies have been carried out in vitro, i.e., cord blood specimens have been tonometrically equilibrated at various oxygen tensions, and the oxygen saturation has been measured.

Beer, Bartels, and Raczkowski (4) and Rooth, Sjöstedt, and Caligara (5) have investigated the in vivo oxygen-dissociation curve by determining the actual oxygen and saturation at the time cord blood is sampled. Unfortunately, the curves so described do not extend into a range of oxygen content physiologic for the normal newborn infant. It is in just this range along the horizontal upper limb of the curve that precise information is necessary for calculation of venous admixture and the diffusion capacity of the lung for oxygen.

One in vitro curve for fetal blood has been published, which extends well into the physiologic range (6). The present investigation represents an attempt at accurate delineation of a comparable in vivo curve.

\section{Methods}

Umbilical arterial blood was obtained by catheter from 13 newborn infants. The infants comprised a crosssection of a typical newborn population (full-term and

* Submitted for publication September 11, 1963; accepted November 29, 1963.

Work supported by training grant (no. T1 AM 5269) from the National Institutes of Arthritis and Metabolic Diseases, U. S. Public Health Service, and by the Association for the Aid of Crippled Children.

$\dagger$ Fellow of the Académie Suisse des Sciences Médicales. Present Address: Clinique Infantile, Hôpital Cantonal, Lausanne, Switzerland. premature infants, infants of diabetic mothers, one Mongol, and four babies with respiratory distress); the precise clinical classification is felt to have little bearing on the behavior of the dissociation curve and is therefore not listed. Since the Bohr-integration procedure used in this laboratory for determination of diffusing capacity requires hypoxic ventilation, we were able to secure several blood samples with oxygen content considerably lower than that normally encountered. Samples were taken anaerobically in heparinized 2-ml syringes and iced until analysis (within 1 hour).

$\mathrm{pH}$ was measured at room temperature with a Cambridge Electron-ray $\mathrm{pH}$ meter and a Beckman one-drop electrode. These values were corrected to $37^{\circ} \mathrm{C}$ with Rosenthal's factors (7).

Oxygen content was measured in duplicate in the KoppNatelson microgasometer in most cases, but some analyses were done in Roughton-Scholander syringes. Oxygen capacity was determined by measuring oxygen content after exposing blood to room air for 15 minutes in a rotating flask, suitable precautions being taken to prevent concentration of the sample by evaporative losses.

Oxygen tension was measured in duplicate by a micromodification (8) of Riley, Campbell, and Shepard's bubble equilibration method (9).

Oxygen saturation was calculated from the formula: 1

$$
S=\frac{\left(\mathrm{Ca}_{\mathrm{O}_{2}}-0.003 \times \mathrm{Pa}_{\mathrm{O}_{2}}\right)}{(\mathrm{Cap}-0.003 \times 150)} \times 100,
$$

where 0.003 is the Van Slyke factor for the amount of oxygen physically dissolved in blood (volume per $100 \mathrm{ml}$ ) under a pressure gradient of $1 \mathrm{~mm} \mathrm{Hg}$ at $37^{\circ} \mathrm{C}$.

Arterial oxygen tension at the observed $\mathrm{pH}$ was recalculated to $\mathrm{pH} 7.4$ for adult blood (10). This correction factor was used to afford a more direct comparison to previously published oxygen-dissociation curves derived by similar means $(4,6)$. Darling, Smith, Asmussen, and Cohen (3) had found no difference between maternal and fetal blood with respect to the effect of $\mathrm{pH}$ change on the placement of the oxygendissociation curve, but a more recent investigation (11) indicates that there may be a significant difference in response to changes in $\mathrm{pH}$.

${ }^{1} \mathrm{~S}=$ percentage of oxygen saturation $; \mathrm{Ca}_{\mathrm{O}_{2}}=$ arterial oxygen content; $\mathrm{Pa}_{2}=$ arterial oxygen tension; $\mathrm{Cap}=$ oxygen capacity. 
TABLE I

Blood oxygenation in newborn infants*

\begin{tabular}{|c|c|c|c|c|c|c|c|c|}
\hline $\begin{array}{c}\text { Infant } \\
\text { no. }\end{array}$ & Age & $\begin{array}{c}100 \\
\mathrm{~F}_{\mathrm{IO}_{2}}\end{array}$ & $\mathrm{pH}$ & $\mathrm{PaO}_{2}$ & $\mathrm{CaO}_{2} \dagger$ & Capt & $\begin{array}{c}\mathrm{St} \\
\left(100 \mathrm{SaO}_{2}\right)\end{array}$ & $\mathrm{PaO}_{2 \mathrm{corr}}$ \\
\hline 1 & $20^{h r s}$ & $\begin{array}{l}15 \\
21\end{array}$ & $\begin{array}{l}7.44 \\
7.45\end{array}$ & $\begin{array}{c}m m \mathrm{Hg} \\
55 \\
79\end{array}$ & $\begin{array}{c}\text { vol/100 ml } \\
17.5 \ddagger \\
18.6 \ddagger\end{array}$ & $\begin{array}{c}\text { vol/100 ml } \\
20.3 \ddagger\end{array}$ & $\begin{array}{l}86.2 \\
91.6\end{array}$ & $\begin{array}{c}m m H g \\
58 \\
83\end{array}$ \\
\hline 2 & $\begin{array}{r}7 \\
30\end{array}$ & $\begin{array}{l}21 \\
15 \\
21\end{array}$ & $\begin{array}{l}7.36 \\
7.38 \\
7.41\end{array}$ & $\begin{array}{l}72 \\
61 \\
56\end{array}$ & $\begin{array}{l}19.0 \ddagger \\
18.1 f \\
17.4 f\end{array}$ & $\begin{array}{l}19.6 \ddagger \\
19.3 \ddagger\end{array}$ & $\begin{array}{l}96.9 \\
92.3 \\
90.2\end{array}$ & $\begin{array}{l}70 \\
59 \\
57\end{array}$ \\
\hline 3 & $\begin{array}{r}3 \\
26\end{array}$ & $\begin{array}{l}25 \\
60 \\
15\end{array}$ & $\begin{array}{l}7.18 \\
7.17 \\
7.40\end{array}$ & $\begin{array}{l}25 \\
58 \\
35\end{array}$ & $\begin{array}{r}6.4 \ddagger \\
14.7 \ddagger \\
12.0 \ddagger\end{array}$ & $\begin{array}{l}18.3 \ddagger \\
16.6 \ddagger\end{array}$ & $\begin{array}{l}35.0 \\
80.3 \\
72.3\end{array}$ & $\begin{array}{l}20 \\
46 \\
35\end{array}$ \\
\hline 4 & $\begin{array}{r}8 \\
31\end{array}$ & $\begin{array}{l}21 \\
15 \\
21 \\
13\end{array}$ & $\begin{array}{l}7.33 \\
7.30 \\
7.34 \\
7.35\end{array}$ & $\begin{array}{l}88 \\
47 \\
82 \\
47\end{array}$ & $\begin{array}{l}14.9 \\
13.5 \\
12.7 \\
11.0\end{array}$ & $\begin{array}{l}15.1 \\
13.1\end{array}$ & $\begin{array}{l}98.7 \\
89.4 \\
96.9 \\
84.0\end{array}$ & $\begin{array}{l}83 \\
42 \\
77 \\
45\end{array}$ \\
\hline 5 & $\begin{array}{l}15 \\
40\end{array}$ & $\begin{array}{l}21 \\
13 \\
21 \\
13\end{array}$ & $\begin{array}{l}7.45 \\
7.46 \\
7.37 \\
7.40\end{array}$ & $\begin{array}{l}68 \\
45 \\
72 \\
45\end{array}$ & $\begin{array}{l}14.6 \\
12.9 \\
15.0 \\
12.2\end{array}$ & $\begin{array}{l}14.8 \\
15.6\end{array}$ & $\begin{array}{l}98.6 \\
87.2 \\
96.2 \\
78.2\end{array}$ & $\begin{array}{l}72 \\
48 \\
70 \\
45\end{array}$ \\
\hline 6 & 4 & $\begin{array}{l}21 \\
13\end{array}$ & $\begin{array}{l}7.36 \\
7.38\end{array}$ & $\begin{array}{l}73 \\
46\end{array}$ & $\begin{array}{l}18.5 \\
16.9\end{array}$ & 18.9 & $\begin{array}{l}97.9 \\
89.4\end{array}$ & $\begin{array}{l}71 \\
45\end{array}$ \\
\hline 7 & 52 & $\begin{array}{l}21 \\
13\end{array}$ & $\begin{array}{l}7.38 \\
7.41\end{array}$ & $\begin{array}{l}85 \\
46\end{array}$ & $\begin{array}{l}18.8 \\
17.7\end{array}$ & 19.8 & $\begin{array}{l}94.9 \\
89.4\end{array}$ & $\begin{array}{l}83 \\
46\end{array}$ \\
\hline 8 & 23 & $\begin{array}{l}21 \\
13\end{array}$ & $\begin{array}{l}7.40 \\
7.40\end{array}$ & $\begin{array}{l}85 \\
40\end{array}$ & $\begin{array}{l}12.9 \\
10.1\end{array}$ & 13.5 & $\begin{array}{l}95.6 \\
74.8\end{array}$ & $\begin{array}{l}85 \\
40\end{array}$ \\
\hline 9 & 24 & 21 & 7.40 & 70 & 19.3 & 21.0 & 91.9 & 70 \\
\hline 10 & 22 days & 21 & 7.37 & 72 & 18.1 & 18.7 & 96.8 & 69 \\
\hline 11 & 33 days & 21 & 7.41 & 57 & 11.3 & 12.4 & 91.1 & 58 \\
\hline 12 & $\begin{array}{r}5 \\
28\end{array}$ & $\begin{array}{l}21 \\
13 \\
21 \\
13\end{array}$ & $\begin{array}{l}7.29 \\
7.33 \\
7.31 \\
7.38\end{array}$ & $\begin{array}{l}82 \\
64 \\
63 \\
34\end{array}$ & $\begin{array}{l}16.6 \\
15.6 \\
14.0 \\
10.6\end{array}$ & $\begin{array}{l}17.3 \\
15.5\end{array}$ & $\begin{array}{l}96.0 \\
90.2 \\
90.3 \\
68.4\end{array}$ & $\begin{array}{l}71 \\
54 \\
55 \\
30\end{array}$ \\
\hline 13 & $\begin{array}{r}8 \\
28\end{array}$ & $\begin{array}{l}21 \\
13 \\
21 \\
13\end{array}$ & $\begin{array}{l}7.30 \\
7.36 \\
7.34 \\
7.42\end{array}$ & $\begin{array}{l}55 \\
21 \\
55 \\
33\end{array}$ & $\begin{array}{r}22.4 \\
7.9 \\
18.9 \\
15.6\end{array}$ & $\begin{array}{r}27.3 \\
22.7\end{array}$ & $\begin{array}{l}82.1 \\
28.9 \\
83.3 \\
68.7\end{array}$ & $\begin{array}{l}50 \\
20 \\
52 \\
34\end{array}$ \\
\hline
\end{tabular}

* $100 \mathrm{~F}_{\mathrm{O}_{2}}=$ inspired oxygen concentration; $\mathrm{Pa}_{2}=$ arterial oxygen tension $\left(\mathrm{Pa}_{\mathrm{O}_{2 \text { corr }}}=\right.$ corrected to $\left.\mathrm{pH} 7.4\right)$; $\mathrm{Ca}_{\mathrm{O}_{2}}=$ arterial oxygen content; $\mathrm{Cap}=$ oxygen capacity; $\mathrm{Sa}_{\mathrm{O}_{2}}=$ fractiona oxygen saturation $\left[\mathrm{Hb} \mathrm{O}_{2} /\left(\mathrm{Hb}+\mathrm{Hb} \mathrm{O}_{2}\right)\right] ;$ $\mathrm{S}=$ percentage of oxygen saturation or $\mathrm{S}=100 \mathrm{Sa}_{\mathrm{O}_{2}}$.

$\uparrow$ Corrected for dissolved oxygen.

‡ Roughton-Scholander syringe.

\section{Results}

These are shown in Table I. $\mathrm{pH}$ varied from 7.18 to 7.46 in low oxygen and from 7.17 to 7.45 in high oxygen, whereas the observed $\mathrm{Pa}_{\mathrm{O}_{2}}$ varied from 21 to $64 \mathrm{~mm} \mathrm{Hg}$ and from 55 to $88 \mathrm{~mm} \mathrm{Hg}$ during low and high oxygen studies, respectively. Saturation ranged from 28.9 to $92.3 \%$ during hypoxia and from 80.3 to 98.7 during air and oxygen breathing.

Calculations. The data of Table I for $\mathrm{Pa}_{\mathrm{O}_{2}}$ and oxygen saturation were grouped together with those of Reardon, Baumann, and Haddad (12) similarly corrected; their data had been obtained by similar methods from a series of normal fullterm infants. The aggregate data were then plotted as $\log S /(100-S)$ vs. $\log \mathrm{Pa}_{\mathbf{O}_{2}}$. The best straight line so described was then calculated by the method of least squares and represented the best solution of the Hill equation (see below) for these data. This estimating equation is presented in the legend for Figure 1, which shows the regression line plotted on linear coordinates.

Comment. Hill's equation, $S / 100=K p^{n} /(1+$ $\left.K p^{n}\right)$, where $S$ is percentage of saturation $(=100$ 




Fig. 1. The in vivo oXYGEN-Dissociation CURVE For Whole bloOd at $\mathrm{PH}$ 7.4 FROM NEWBORN INFANTS. $\times$, Reardon and co-workers (12); $\bullet$, Nelson and associates. The regression line is calculated from the estimating equation, $\log \mathrm{S} /(100-\mathrm{S})=-3.041+2.287 \log \mathrm{Pa}_{0_{2}} ; r=0.761, t=8.04$, $p \ll 0.001$, and $\sigma y_{x}=0.231$.

$\left.\mathrm{Sa}_{\mathrm{O}_{2}}\right), p$ is oxygen tension, and $K$ and $n$ are constants may be rewritten as $S /(100-S)=K p^{n}$, or, taking $\operatorname{logs}, \log S /(100-S)=\log K+n(\log$ $p)$. Thus $n$ describes the slope of the hemoglobin dissociation curve for oxygen. However, a single value for $n$ cannot completely describe the curve because its slope varies (13); $n$ tends to approximate 2.5 between 20 to $80 \%$ saturation, but it approaches 1 at the extreme ends of the curve (below $20 \%$ and over $80 \%$ saturation). Our slope $(n=2.287)$ is considerably less than those previously reported (3-5), because our primary data were obtained in vivo after birth from arterial blood better oxygenated than that of the umbilical cord used by previous workers. In short, our values lay more on the horizontal portion of the sigmoid oxygen-dissociation curve (Figure 2 ).

Just as Rooth and associates (5) found that their in vivo curve closely matched the in vitro curves of Darling and co-workers (3) and Beer and colleagues (4) in the steep portion, so our own in vivo data for the upper and (horizontal portion) of the curve coincides with the in vitro data of Edwards and Ross (6) (cf. Figure 2).

The concentration of fetal hemoglobin has not been reported in any of the previous or present studies but must have varied considerably. Despite this, Figure 2 shows a remarkable similarity among measurements of all investigators in all portions of the curve and tends to substantiate Prystowsky's finding that the position of the fetal dissociation curve bears no relationship to the concentration of fetal hemoglobin (14).

The best average values of $S$ at $\mathrm{Pa}_{\mathrm{O}_{2}}$ of 5,15 , 25, 40, and $90 \mathrm{~mm} \mathrm{Hg}$ have been used to derive constants for Gomez' equation for the oxygendissociation curve $(15):^{2}$

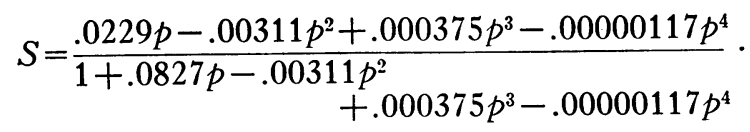

The curve predicted by this equation for fetalneonatal blood at $\mathrm{pH} 7.4$ is drawn in Figure 2

${ }^{2}$ The basic equation is

$$
C(p)=\frac{a_{1} p+a_{2} p^{2}+a_{3} p^{3}+a_{4} p^{4}}{1+\left(\sigma+a_{1}\right) p+a_{2} p^{2}+a_{3} p^{3}+a_{4} p^{4}},
$$

where $C(p)$ is the concentration of $\mathrm{Hbo}_{2}, p$ is oxygen tension in millimeters $\mathrm{Hg}$, and $a_{1} ; a_{2}, a_{3}, a_{4}$, and $\sigma$ are constants having the values: $a_{1}=.0229, a_{2}=-.00311, a_{3}=.000375$, $a_{4}=-.00000117$, and $\sigma=.0598$. 
(solid line) and compared to the corresponding curve for adult blood (16) (dashed line). The close similarity of slope between the adult and fetal-neonatal curves at $\mathrm{pH}$ is obvious in Figure 2. In fact, the fetal-neonatal curve exactly coincides with the adult curve for $\mathrm{pH}$ 7.6. This might imply, as Allen, Wyman, and Smith have suggested (17), that the differences in oxygen equilibria between adult and fetal hemoglobin are related more to the environment of the hemoglobin molecule than to any basic differences between the two types of hemoglobin molecule. Indeed, Allen and co-workers (17) found no difference between the dissociation curves of fetal and adult hemoglobin after dialysis, and Rooth, Sommerkamp, and Bartels (18) have been able to shift the position of the dissociation curve by varying base excess and cation concentration in the hemoglobin solution.

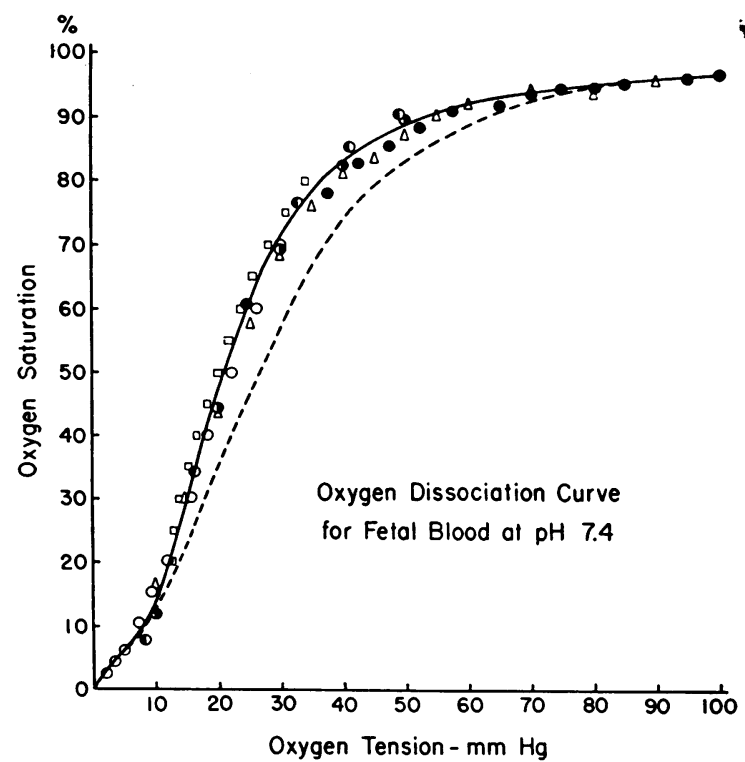

Fig. 2. The oXygen-Dissociation CURVE for fEtal BLOOD AT PH 7.4. The solid line represents the oxygendissociation curve predicted from Gomez' (15) equation (see text); the broken line is the oxygen-dissociation curve observed by Dill (10) for adult blood. In vitro data for fetal blood were taken from the studies of Darling and colleagues (3), 1 ; Hellegers and Schruefer (11), $\square$; and Edwards and Ross (6), $\triangle$. In vivo data were taken from the studies of Beer and co-workers (4), $O$; Rooth and associates (5), $D$; and the combined data of Reardon and present authors, $\bullet$.

\section{Summary}

1) Data for oxygen saturation and tension in the blood of newborn infants have been presented that accurately define the oxygen-dissociation curve in the physiologic range above $80 \%$ saturation.

2) Specific constants have been derived from these data for the equation that describes oxygen dissociation. This equation accurately fits the empirical data for oxygen dissociation from 0 to $100 \%$ saturation.

3) The oxygen-dissociation curve for fetalneonatal blood at $\mathrm{pH} 7.4$ is identical with that for adult blood at $\mathrm{pH} 7.6$.

\section{Acknowledgment}

The authors are indebted to Professor Cyril A. Nelson for his kind assistance in deriving constants for the oxygen-dissociation equation.

\section{References}

1. Eastman, N. J., E. M. K. Geiling, and A. M. deLawder. Foetal blood studies. IV. The oxygen and carbon-dioxide dissociation curves of foetal blood. Bull. Johns Hopk. Hosp. 1933, 53, 246.

2. Leibson, R. G., I. I. Likhnitzky, and M. G. Sax. Oxygen transport of the foetal and maternal blood during pregnancy. J. Physiol. (Lond.) 1936, 87, 97.

3. Darling, R. C., C. A. Smith, E. Asmussen, and F. M. Cohen. Some properties of human fetal and maternal blood. J. clin. Invest. 1941, 20, 739.

4. Beer, R., H. Bartels, and H. A. Raczkowski. Die Sauerstoffdissoziationskurve des fetalen Blutes und der Gasaustauch in der menschlichen Placenta. Pflügers Arch. ges. Physiol. 1955, 260, 306.

5. Rooth, G., S. Sjöstedt, and F. Caligara. The "in vivo" foetal oxygen dissociation curve. Biol. Neonat. (Basel) 1959, 1, 61.

6. Edwards, M. J., and B. B. Ross. Graphical representation of respiratory gas dissociation characteristics of fetal and maternal blood. J. appl. Physiol. 1959, 14, 454.

7. Rosenthal, T. B. The effect of temperature on the $\mathrm{pH}$ of blood and plasma in vitro. J. biol. Chem. 1948, 173, 25.

8. Bates, G. D., and T. K. Oliver, Jr. A micromodification of the bubble method for direct determination of blood gas tensions. J. appl. Physiol. 1962, $17,743$.

9. Riley, R. L., E. J. M. Campbell, and R. H. Shepard. A bubble method for estimation of $\mathrm{P}_{\mathrm{CO}_{2}}$ and $\mathrm{P}_{\mathrm{O}_{2}}$ in whole blood. J. appl. Physiol. 1957, 11, 245.

10. Dill, D. B. in Handbook of Respiration. Philadelphia, W. B. Saunders, 1958, p. 73. 
11. Hellegers, A. E., and J. J. P. Schruefer. Nomograms and empirical equations relating oxygen tension, percentage saturation, and $\mathrm{pH}$ in maternal and fetal blood. Amer. J. Obstet. Gynec. 1961, 81, 377.

12. Reardon, H. S., M. L. Baumann, and E. J. Haddad. Chemical stimuli of respiration in the early neonatal period. J. Pediat. 1960, 57, 151.

13. Roughton, F. J. W. in Handbook of Respiratory Physiology. USAF School of Aviation Medicine (Project \#21-2301-0003), 1954, p. 65.

14. Prystowsky, H., A. Hellegers, J. Cotter, and P. Bruns. Fetal blood studies. XII. On the relationship between the position of the oxygen dissociation curve of human fetal blood and adult-fetal hemoglobin. Amer. J. Obstet. Gynec. 1959, 77, 585.

15. Gomez, D. M. Considerations of oxygen-hemoglobin equilibrium in the physiological state. Amer. J. Physiol. 1961, 200, 135.

16. Dill, D. B. in Handbook of Respiratory Data in Aviation. Washington, D. C., 1944.

17. Allen, D. W., J. Wyman, Jr., and C. A. Smith. The oxygen equilibrium of fetal and adult human hemoglobin. J. biol. Chem. 1953, 203, 81.

18. Rooth, G., H. Sommerkamp, and H. Bartels. The influence of base excess and cation concentration in the red cells on the position of the oxygen dissociation curve. Clin. Sci. 1962, 23, 1. 